PARKES (James). - Historia del pueblo judio. Trad. Juan J. Thomas, Buenos Aires, Editorial Paidós, 1965, 274 págs.

Todos aquêles que, por uma razão ou outra, procuram estabelecer as bases da Civilização Ocidental terão, fatalmente, que recorrer à História dos hebreus. Seja porisso, seja pelo interêsse a respeito dos judeus em si, vasta é a bibliografia histórica referente a êsse povo. Mas pelas próprias características dos judeus, reais ou esteriotipadas, as obras a seu respeito são, muitas vêzes, inexatas. Ora, é um panegírico incondicional, ora uma. crítica tendenciosa, às vêzes aspectos secundários analisados em profundidade, outras, coisas importantíssimas tratadas com negligência.

Nenhum dêsses é o caso do presente volume, pequeno, escrito pelo historiador inglês James Parkes, profundo conhecedor do judaísmo, embora êle não seja de origem judaica. Trata-se de obra clara que, inteligente, não se perde no emaranhado do falso intelectualismo.

A grosso modo poderíamos dividir o trabalho em duas partes, quantitativamente desiguais: a primeira, correspondendo ao prólogo e ao primeiro capítulo, trata dos hebrius $\mathrm{cm}$ sua terra; e a segunda, correspondendo aos demais capítulos, procura retratar es "encontros" entre judeus e os vários povos ou culturas, ao longo de quase 20 séculos de diáspora. Em outras palavras, de um lado os preparativos para sobreviver, e de outro, a própria sobrevivência.

Quais seriam, pois, as causas desta sobrevivência? Para Parkes, grande parte da responsabilidade dêsse fato caberia a Esdras, como condutor político e religioso dos judeus libertados por Ciro aos babilônios. Estabeleceu logo seus objetivos, em número de três:

\footnotetext{
"En primeiro lugar queria que todo el pueblo renovasse el pacto de obediencia a la voluntad de Diós ... Su segundo objetivo era el de purfficar la nación de los pecados ... Su tercer objetivo era el conseguir que todo el pueblo praticase la reltgion en la vida diária" (págs. 18 e 19).
}

Esdras não cra, porém, nenhum sonhador. Tinha consciência de que deveria dispor de instrumentos com os quais pudesse atingir seus objetivos. E soube escolhê-los e aplicá-los com a habilidade dos grandes líderes:

"la sinagoga, las Escrituras y el mastro de la Toră" (pág. 20) .

Este tríplice instrumental, aplicado através dos tempos é que teria, para Parkes, a responsabilidade da sobrevivência do povo judeu.

Após discutir esta sua idéia, passa o Autor a colocar o povo judeu diante de vários povos e culturas, o primeiro dos quais o Islão. Fala Parkes das razões de ordem econômica que possibilitaram a tolerância dos árabes para com os judeus, seus súditos. Era, já se vê, uma questão de impostos (pág. 55). Esses mesmos judeus tiveram grande importância econômica e cultural na expansão mourisca e o exemplo de Maimônides se impõe, mesmo pơrque

"tođa la judeidad quedó hondamente afectada por las opiniones concisas y desafiantes del atareado doctor y filosofo de Fustat, ouien provocó una controversia que no tiene igual en la historia judia hasta la época de spinoza" (pág. 67). 
Claro que a liberdade que os judeus tinham naquele tempo facilitava a assimilação de valores culturais islâmicos.

Já com o cristianismo isto não aconteceria. O Autor explica que tudo se deve à identificação tão grande entre o judaísmo e o cristianismo pois

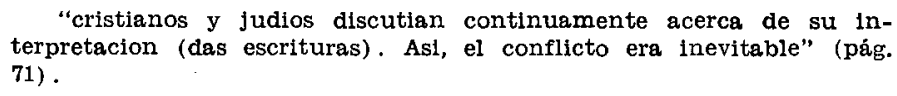

"cristianos y judios discutian continuamente acerca de su interpretacion (das escrituras). Ası, el conflicto era inevitable" (pág. 71).

Segue o autor mostrando e exemplificando a intolerância nas relações judiocristãs, para concluir que esta intolerância só chegaria a um fim no século XIX com a tendência laica do Estado.

Após colocar tôda a problemática do judeu no gueto, o Autor diz de como, a partir do aparecimento das idéias dos direitos do homem, começa a haver uma visão diferente do mundo para com êle. Acontece, porém, o previsível: após relegado a uma condição de minoria e de ser incompreendido é marginalizado, é o judeu que já não pode compreender o mundo que o cerca. Vale a pena citar o caso de Moisés Mendelssohn (1729-1786):

\begin{abstract}
"Era sinceramente religioso y una de sus más grandes obras consistia en trađucir las Escrituras en un buen alemán, para que su pueblo se liberara del dialecto idísh. Encantó a los salones de Berlin con su explicación fllosófica del judaismo ... y murió respetado de todos. Pero sus hijos no encontraron un lugar en el judaismo del siglo XVIII y se convertieron al cristianismo" (pág. 148).
\end{abstract}

Aos poucos, porém, foi o judeu se emancipando, desprendendo-se do gueto e penetrando na sociedade burguesa e urbana. Mas não se distribuia uniformemente na sociedade em que havia se tornado membro com todos os direitos. Além de banqueiros (como os Rothschilds) e industriais (os Hirsch)

"Ia fe en una justicia social fundamental ... convertia a los judiós en buenos políticos del siglo XIX" enquanto que "la tradicion de la integridad intelectual del guetto hacía de ellos buenos científicos" (pág. 168).

Parkes fala ainda do status do judeu na Rússia revolucionária onde

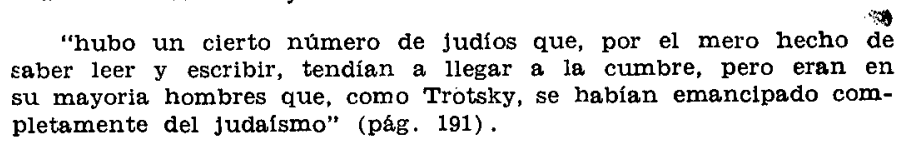

"hubo un cierto número de judíos que, por el mero hecho de saber leer y escribir, tendian a llegar a la cumbre, pero eran en su mayoria hombres que, como Trotsky, se habian emancipado completamente del judaísmo" (pág. 191).

Até que ponto esta emancipação dentro da Rússia Taarista ou Socialista foi aceita e conduziu a um bem estar dentro da comunidade é o que discute o Autor a seguir.

Fala ainda Parkes a respeito de Pinsker, com sua "Autoemancipação" (pág. 205) e de Herzl e seu "Estado Judeu" (pág. 210), que estabeleceriam aquelas que seriam as bases do sionismo moderno. Depois de começarm a surgir os frutos dessas teorias, com fluxos migratórias da Europa Central para a Palestina, há o nazismo que acelera o surgimento do moderno Estado de Israel. Conclui Parkes vaticinando que

“es razonable esperar que nosotros los gentiles - cristianos, musulmanes, humanistas y otros - a quienes el judio ha encon- 
trađo hasta ahora, encontremos por nuestra parte al judio, aprovechando el encuentro" (pág. 268).

Trata-se, portanto, de uma visão dinâmica, já que o Autor não se fixa em nenhum princípio dogmático, verificando, como historiador, as interrelações judeu-mundo. Em livro de bolso, barato, mas sempre decentemente cuidado, com bibliografia em inglês e espanhol, além de tradução esmerada, a obra de Parkes é indicada para todos aquêles que quiserem ter uma iniciação segura na longa e acidentada história do povo judeu.

\section{JAIME PINSKY}

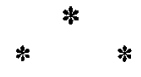

Etudes d'archéologie aérienne. Paris. S.E.V.P.E.N. Publicação da "École Pratique des Hautes Études. VIe section". Coleção "Mémoires de Photo-Interprétation n n $^{\circ} .1966$.

$R$. Chevalier sublinha inicialmente a contribuição da fotografia aérea para a pesquisa dos habitats desaparecidos. $R$. Agathe nos leva à descoberta do habitat rural galo-romano na Picardia. $R$. Chevalier mostra como os métodos modernos de prospeção geofísica completam os dados fornecidos pela foto-interpretação com uma aplicação às villas romanas do Somme. O General G. Schmiedt (IGM, Florença) mostra, enfim, a contribuição da detecção aérea para a reconstrução das paisagens humanas da Itália antiga.

Ésse livro de 160 páginas comporta uma ilustração excepcional de cêrca de 150 fotografias.

E. S. P.

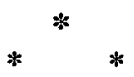

Mélanges Piganiol. Paris. S.E.V.P.E.N. Publicação da "Ecole Pratique des Hutes Etudes. VIe section". Coleção "Bibliothèque Générale". 1966. 3 volumes.

André Piganiol, nascido a 17 de janeiro de 1883 no Havre, ex-aluno da Ecole Norme Superiéure, agrégé de História e Geografia, antigo membro da Ecole Française de Rome, professor nas Universidades de Lille, Estrasburgo, depois Paris, nas Escolas Normais Superiores, enfim no Colégio de França (1942), membro da $A c a-$ demie des Inscriptions et Belles-Lettres (1945), Diretor da II Circunscrição das Antigüidades históricas (1951), Doutor honoris causa pela Universidade de Gand, membro das Academias de Mogúncia e Munique, publicou numerosos estudos fundamentais sôbre a Antigüidades greco-romana, a epigrafia e a arqueologia.

Formou numerosos discípulos, dos quais muitos estrangeiros, que the ofereceram três volumes de Mélanges d'archéologie et d'histoire, editadas por $\mathrm{R}$. Che- 